\title{
Pengembangan Media Interaktif Pengenalan Sistem Tata Surya Menggunakan Framework MDLC
}

\author{
Ika Asti Astuti ${ }^{1}$, Aris Harwanto ${ }^{2}$, Tonny Hidayat ${ }^{3}$ \\ ${ }^{1,2}$ Sistem Informasi Universitas Amikom Yogyakarta \\ ${ }^{3}$ Manajemen Informatika Univesitas Amikom Yogyakarta \\ J1. Ring Road Utara, Condong Catur, Sleman, Yogyakarta, Telp. (0274) 884201-207 \\ e-mail: ${ }^{1}$ asti@amikom.ac.id, ${ }^{2}$ aris8214@students.amikom.ac.id, ${ }^{3}$ tonny@amikom.ac.id
}

\begin{abstract}
Abstrak
Pembelajaran tentang pengenalan sistem tata surya untuk siswa sekolah dasar yang masih bersifat teacher-centered menjadi salah satu permasalahan yang membuat siswa kurang aktif karena tidak memberikan respons timbal balik secara realtime. Maka dari itu, perlu adanya sebuah media pembelajaran yang dapat meningkatkan keaktifan siswa dan memberikan respons timbal balik secara realtime. Media pembelajaran interaktif dapat memperjelas visualisasi pembelajaran karena mengandung unsur multimedia meliputi teks, gambar, audio, video, serta animasi sehingga siswa dapat lebih memahami pembelajaran dan meningkatkan keaktifan siswa karena mendapatkan respons timbal balik secara realtime. Metode pengembangan yang digunakan yaitu Multimedia Development Life Cycle yang terdiri dari 6 tahapan yaitu konsep, perancangan, pengumpulan bahan, pembuatan, pengujian, dan distribusi. Metode pengujian media pembelajaran interaktif yaitu dengan memberikan kuesioner kepada ahli materi dan juga responden. Setelah itu, dilakukan uji coba kepada kelompok $(n=21)$ menggunakan One Group Pretest Postest. Hasil penelitian dianalisis menggunakan paired t-test, menunjukkan bahwa adanya peningkatan hasil pembelajaran sebesar 22,27\% antara sebelum dan sesudah menggunakan media pembelajaran interaktif.
\end{abstract}

Kata kunci: Media Interaktif, MDLC, Sistem Tata Surya, Sekolah Dasar.

\begin{abstract}
The learning process about introduction of a solar system for elementary school students that are still teacher-centered is one of the problems that make students less active because it does not provide reciprocal responses in real time. Therefore, it is necessary to have a media, which can provide more real visualization of the solar system, increase student activity, and provide reciprocal responses in real time. Interactive learning media can clarify the visualization of learning content because it contains multimedia elements including text, images, audio, video and animation so students can understand the lesson better and increase student activity because they get reciprocal responses in real time. The development method which writer used is Multimedia Development Life Cycle that consists of 6 stages, namely: concept, design, material collection, manufacture, testing and distribution. The test method for validating interactive learning media is by giving questionnaires to material experts and also respondents. After that a trial was conducted on the group $(n=21)$ using the One Group Pretest Posttest. The results of the study were analyzed using a paired t-test, indicating that there was an increase in learning outcomes of $22.27 \%$ between before and after using interactive learning media.
\end{abstract}

Keywords: Interactive Media, MDLC, Solar System, Elementary School.

\section{Pendahuluan}

Salah satu materi yang diajarkan pada siswa kelas VI Sekolah Dasar adalah materi Sistem Tata Surya. Berdasarkan hasil observasi yang dilakukan, banyak siswa mengalami kesulitan dalam menjelaskan kembali pembelajaran sistem tata surya karena penggunaan metode teacher-centered dalam menyampaikan materi. Teacher-centered merupakan salah satu strategi pembelajaran di mana guru biasanya menggunakan metode ceramah dalam menyampaikan pembelajaran [1]. Menurut [2], pembelajaran yang bersifat teachercentered menjadi salah satu permasalahan yang membuat siswa kurang aktif dalam kelas. Selain itu, berdasarkan hasil observasi saat pembelajaran, penggunaan media pembelajaran seperti buku, alat peraga berupa replika tata surya, dan papan tulis kurang bisa membantu guru dalam menggambarkan sistem tata 
surya. Meskipun sudah memiliki fasilitas yang mendukung seperti laptop dan proyektor, namun guru masih belum memanfaatkan media pembelajaran interaktif sebagai media tambahan dalam menerangkan materi.

Media pembelajaran digunakan sebagai alat bantu proses belajar mengajar [3]. Segala sesuatu yang dapat dipergunakan untuk merangsang pikiran, perasaan, perhatian, dan kemampuan atau ketrampilan belajar sehingga dapat mendorong terjadinya proses belajar. Sedangkan menurut [4], media pembelajaran adalah sarana fisik untuk menyampaikan isi/materi pembelajaran seperti buku, film, video, dan sebagainya. Kemudian menurut [5], mengungkapkan bahwa media pembelajaran adalah sarana komunikasi dalam bentuk cetak maupun pandang-dengar, termasuk teknologi perangkat keras.

Multimedia interaktif merupakan salah satu metode yang dapat digunakan sebagai media pembelajaran yang menggabungkan teks, grafik, video, animasi, dan suara [6] untuk menyampaikan suatu pesan dan informasi melalui media elektronik seperti komputer dan perangkat elektronik lainnya. Multimedia interaktif telah berhasil menambah keaktifan siswa dalam pembelajaran [7] dan menambah penguasaan konsep pada siswa [8].

Berdasarkan uraian di atas, maka dibutuhkan pembuatan media interaktif sebagai media pembelajaran untuk siswa kelas VI khususnya pada materi Pengenalan Sistem Tata Surya di Sekolah Dasar. Selain bertujuan untuk membantu guru dalam menyampaikan materi kepada siswa, multimedia interaktif yang dibuat juga diharapkan dapat menambah keaktifan siswa pada proses pembelajaran.

\section{Metode Penelitian}

Metode penelitian yang digunakan termasuk ke dalam metode research and development yang diadopsi dari penelitian oleh [9]. Penelitian terbagi menjadi tiga tahapan utama, yaitu: 1) Studi Pendahuluan; 2) Pengembangan Model; dan 3) Uji Validitas Model. Berikut merupakan desain penelitian yang digunakan dalam penelitian ini.

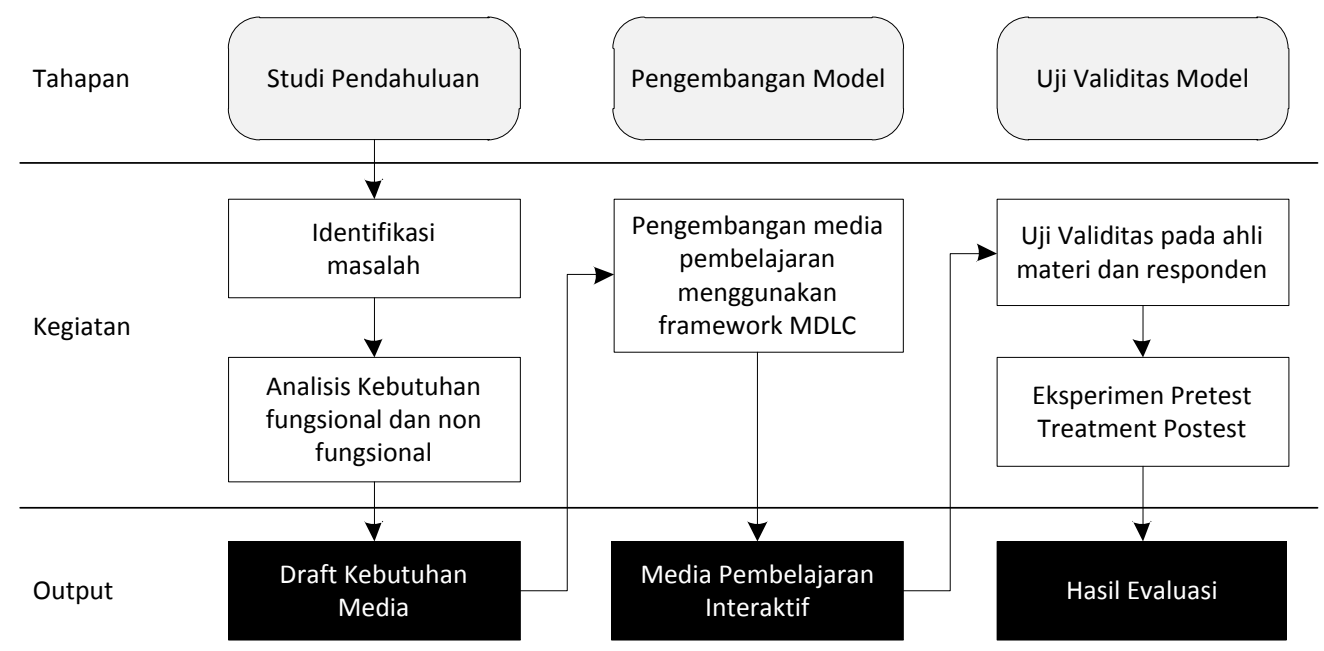

Gambar 1. Desain penelitian.

Terdapat tiga tahapan utama dalam penelitian yaitu studi pendahuluan, pengembangan model, dan uji validitas model. Pada tahapan studi pendahuluan, dimulai dengan identifikasi masalah dan melakukan analisis kebutuhan fungsional dan non fungsional. Hasil dari tahapan ini yaitu draft kebutuhan media pembelajaran yang akan dikembangkan. Tahapan kedua yaitu melakukan pengembangan model dengan menggunakan framework MDLC (Multimedia Life Development Cycle). Hasil dari penelitian ini yaitu sebuah media pembelajaran interaktif yang kemudian masuk ke tahapan uji validitas model kepada ahli materi dan responden. Setelah itu, dilakukan eksperimen media pembelajaran dengan memberikan pretest dan posttest kepada responden.

\subsection{Metode pengujian}

Metode pengujian dalam penelitian ini menggunakan eksperimental semu (Quasi Eksperimen) dengan desain penelitian yang digunakan yaitu One Group Pretest Postest, di mana tidak ada kelompok kontrol/pembanding. Kelompok yang ada diberi pretest, kemudian diberikan perlakuan dan terakhir diberikan posttest yang dilaksanakan pada guru wali kelas VI dan siswa-siswi kelas VI (n=21) di SD Negeri pada persamaan 1 . 
Keterangan:

$$
\begin{array}{lll}
O_{1} & X & O_{2}
\end{array}
$$

$O_{1}=$ Pretest , tes dilakukan sebelum diberikan perlakuan

$X=$ Treatment, perlakuan dengan menggunakan media pembelajaran

$\mathrm{O}_{2}=$ Posttest , tes dilakukan setelah diberikan perlakuan

Pretest yang dilakukan yaitu dengan memberikan tes awal kepada siswa untuk menjawab soal yang berada di buku pelajaran yang sebelumnya belum ada jawaban, kemudian guru akan menilai jawaban siswa. Setelah itu, treatment dilakukan dengan menggunakan multimedia interaktif yang telah dirancang sebelumnya sebagai media pembelajaran. Terakhir, dilakukan pemberian tes akhir kepada siswa untuk menjawab soal kembali setelah diberikan treatment. Hasil tes awal dan akhir dari siswa dianalisis menggunakan software SPSS. Rancangan penelitian ini bertujuan untuk mengetahui apakah ada pengaruh penggunaan media pembelajaran terhadap hasil belajar siswa.

\subsection{Instrumen penelitian}

Terdapat dua instrumen penelitian yaitu instrumen yang digunakan untuk kegiatan validasi media pembelajaran berbentuk kuesioner dan instrumen yang digunakan untuk eksperimen berbentuk soal pretest dan posttest. Terdapat dua jenis instrumen penilaian berbentuk kuesioner yang diberikan kepada guru dan responden. Kuesioner penilaian untuk guru menggunakan skala Likert yang terdiri dari 5 skala yaitu Sangat Kurang - Kurang - Cukup - Baik - Sangat Baik, dimaksudkan untuk menilai media pembelajaran pada 3 aspek, yaitu aspek pembelajaran \& kebahasan (Tabel 1), aspek isi (Tabel 2), dan aspek tampilan dan suara (Tabel 3).

Tabel 1. Kuesioner guru "Aspek Pembelajaran \& Kebahasan”.

\begin{tabular}{|c|c|c|c|c|c|c|}
\hline No. & Indikator & SK & $\mathbf{K}$ & $\mathbf{C}$ & $\mathbf{B}$ & SB \\
\hline 1. & Sistematika penyajian materi & & & & & \\
\hline 2. & Kejelasan petunjuk aplikasi & & & & & \\
\hline 3. & Pemberian motivasi belajar & & & & & \\
\hline 4. & $\begin{array}{l}\text { Penggunaan bahasa yang sederhana, lugas dan mudah } \\
\text { dipahami (komunikatif) }\end{array}$ & & & & & \\
\hline 5. & Penyajian kalimat (tidak mengandung ambiguitas) & & & & & \\
\hline 6. & $\begin{array}{l}\text { Kesesuaian struktur kalimat dengan tingkat penguasaan } \\
\text { kognitif sasaran / siswa SD }\end{array}$ & & & & & \\
\hline
\end{tabular}

Pada Tabel 1, terdapat 6 indikator penilaian untuk aspek pembelajaran dan kebahasan, yaitu sistematika penyajian materi, kejelasan petunjuk aplikasi, pemberian motivasi belajar, penggunaan bahasa yang sederhana, lugas dan mudah dipahami (komunikatif), penyajian kalimat (tidak mengandung ambiguitas), dan kesesuaian struktur kalimat dengan tingkat penguasaan kognitif sasaran/siswa SD.

Tabel 2. Kuesioner guru "Aspek Isi”.

\begin{tabular}{|c|c|c|c|c|c|c|}
\hline No. & Indikator & SK & $\mathbf{K}$ & $\mathbf{C}$ & $\mathbf{B}$ & SB \\
\hline 1. & Kesesuaian materi yang disampaikan di sekolah & & & & & \\
\hline 2. & $\begin{array}{l}\text { Kesesuaian gambar dan animasi untuk memperjelas } \\
\text { materi }\end{array}$ & & & & & \\
\hline 3. & $\begin{array}{l}\text { Kesesuaian materi yang disajikan dengan kurikulum } \\
\text { yang berlaku }\end{array}$ & & & & & \\
\hline
\end{tabular}

Pada Tabel 2, terdapat 3 indikator penilaian untuk aspek isi yaitu kesesuaian materi yang disampaikan di sekolah, kesesuaian gambar dan animasi untuk memperjelas materi, dan kesesuaian materi yang disajikan dengan kurikulum yang berlaku.

Tabel 3. Kuesioner guru “Aspek Tampilan dan Suara”.

\begin{tabular}{|c|c|c|c|c|c|c|}
\hline No. & Indikator & SK & $\mathbf{K}$ & $\mathbf{C}$ & $\mathbf{B}$ & SB \\
\hline 1. & Pemilihan jenis huruf dan ukuran huruf & & & & & \\
\hline 2. & Keterbacaan teks & & & & & \\
\hline 3. & Tampilan gambar dan animasi & & & & & \\
\hline 4. & Kejelasan warna gambar dan animasi & & & & & \\
\hline 5. & Desain screen & & & & & \\
\hline 6. & Tata letak (layout) & & & & & \\
\hline 7. & Komposisi layout & & & & & \\
\hline 8. & Ketepatan pemilihan warna & & & & & \\
\hline
\end{tabular}




\begin{tabular}{cl}
\hline 9. & Kesesuaian karakter dengan tema media pembelajaran \\
\hline 10. & Kesesuaian musik dengan tema media pembelajaran \\
\hline
\end{tabular}

Pada Tabel 3, terdapat 10 indikator penilaian untuk aspek tampilan dan suara yaitu pemilihan jenis huruf dan ukuran huruf, keterbacaan teks, tampilan gambar dan animasi, kejelasan warna gambar dan animasi, desain screen, tata letak (layout), komposisi layout, ketepatan pemilihan warna, kesesuaian karakter dengan tema media pembelajaran, dan kesesuaian musik dengan tema media pembelajaran.

Sedangkan kuesioner penilaian untuk siswa menggunakan skala Likert yang terdiri dari 4 skala yaitu Sangat Kurang - Kurang - Baik - Sangat Baik untuk memudahkan siswa dalam memilih. Isi dari kuesioner penilaian siswa meliputi 6 indikator yaitu kejelasan teks, kemudahan memahami materi, kemudahan penggunaan aplikasi, gambar dan animasi menarik, narasi dan musik terdengar, dan daya tarik penggunaan aplikasi sebagai media pembelajaran di kelas (Tabel 4).

Tabel 4. Kuesioner siswa.

\begin{tabular}{|c|c|c|c|c|c|}
\hline No. & Indikator & SK & $\mathbf{K}$ & $\mathbf{B}$ & SB \\
\hline 1. & Kejelasan teks / tulisan mudah dibaca & & & & \\
\hline 2. & Kemudahan memahami materi & & & & \\
\hline 3. & Kemudahan penggunaan aplikasi & & & & \\
\hline 4. & Gambar dan animasi menarik & & & & \\
\hline 5. & Narasi dan musik terdengar & & & & \\
\hline 6. & $\begin{array}{l}\text { Daya tarik penggunaan aplikasi sebagai media } \\
\text { pembelajaran di kelas }\end{array}$ & & & & \\
\hline
\end{tabular}

\section{Hasil dan Pembahasan}

\subsection{Studi Pendahuluan}

Identifikasi masalah yang digunakan yaitu wawancara langsung dengan kepala sekolah dan wali kelas VI SD Negeri 1 Jatimulyo. Identifikasi masalah juga didapat dari hasil observasi yang dilakukan di kelas saat pembelajaran berlangsung. Hasil dari wawancara dan observasi ini yang kemudian digunakan untuk membuat rumusan kebutuhan media pembelajaran.

Analisis kebutuhan sistem yang dilakukan pada penelitian ini dibagi menjadi dua yaitu kebutuhan fungsional dan kebutuhan non fungsional. Analisis kebutuhan fungsional dilakukan untuk merumuskan kebutuhan menu apa saja yang harus ada di dalam media pembelajaran. Sedangkan analisis kebutuhan non fungsional digunakan untuk merumuskan spesifikasi kebutuhan perangkat yang digunakan meliputi hardware (perangkat keras), software (perangkat lunak), dan brainware (pengguna).

\subsection{Pengembangan Model}

Model pengembangan yang digunakan yaitu Multimedia Development Life Cycle (MDLC) menurut Luther dalam [10] yang terdiri dari 6 tahap yaitu Konsep (Concept), Perancangan (Design), Pengumpulan Data (Material Collecting), Pembuatan (Assembly), Pengujian (Testing), dan Distribusi (Distribution) [11].

\section{Concept (Konsep)}

Tahap ini mendefinisikan tujuan penelitian dan menentukan jenis aplikasi multimedia yang akan dibuat. Tahap ini juga akan menentukan jenis aplikasi (presentasi, interaktif, dan lain-lain) dan tujuan aplikasi (hiburan, pelatihan, pembelajaran, dan lain-lain).

Konsep yang digunakan dalam pembuatan aplikasi interaktif ini adalah program aplikasi media pembelajaran untuk menunjang proses belajar mengajar pada SD N 1 Jatimulyo. Sehingga, secara otomatis pengguna dari sistem ini adalah siswa-siswi khususnya kelas VI dan guru pada SD Negeri 1 Jatimulyo. Aplikasi ini untuk membantu siswa dalam memahami materi yang diajarkan serta membantu guru dalam kegiatan belajar mengajar.

\section{Design (Perancangan)}

Dalam tahap ini dilakukan pembuatan desain visual tampilan interface dan storyboard. Pada tahap ini, dilakukan pembuatan rancangan naskah untuk menggambarkan deskripsi tiap scene/halaman. Setelah itu, dilakukan penentuan tautan dari satu scene ke scene lainnya dengan menggunakan perancangan struktur navigasi. Untuk menggambarkan desain dari aplikasi yang akan dibuat, digunakan layout sederhana untuk mempermudah pengguna dalam penggunaan aplikasi. Berikut merupakan tabel perancangan naskah/rencana scene yang dibuat. 
Tabel 5. Perancangan naskah.

\begin{tabular}{cll}
\hline No & \multicolumn{1}{c}{ Menu } & \multicolumn{1}{c}{ Keterangan } \\
\hline 1. & Tampilan Intro & $\begin{array}{l}\text { Menampilkan tampilan awal aplikasi berupa teks "Pengenalan Sistem Tata Surya, } \\
\text { terdapat 2 tombol menuju ke Menu Utama. }\end{array}$ \\
\hline 2. & Menu Utama & $\begin{array}{l}\text { Menampilkan beberapa menu seperti Menu Materi, Menu Kuis, Menu Tentang dan } \\
\text { Tombol Sound dan Tombol Keluar, di mana tiap-tiap menu menuju ke Sub Menu } \\
\text { masing-masing. }\end{array}$ \\
\hline 3. & Menu Materi & $\begin{array}{l}\text { Menampilkan Sub Materi Planet, Gerhana, Rotasi \& Revolusi, Benda Langit dan } \\
\text { Satelit dan beberapa pilihan tombol-tombol Sub Menu Materi Planet, terdapat } \\
\text { tombol sound dan tombol keluar. }\end{array}$ \\
\hline 4. & Sub Menu Materi & $\begin{array}{l}\text { Berisi informasi mengenai sub menu yang dipilih seperti informasi tata surya dan } \\
\text { planet, gerhana, rotasi \& revolusi, benda langit dan satelit, juga berisi animasi dan } \\
\text { juga gambar. }\end{array}$ \\
\hline 5. & Menu Kuis & Menampilkan informasi permainan. \\
\hline 6. & Menu Tentang & $\begin{array}{l}\text { Menampilkan informasi dari pembuat aplikasi dan informasi tentang tombol-tombol } \\
\text { di aplikasi. }\end{array}$ \\
\hline 7. & Tombol Keluar & Pilihan untuk keluar atau tidak dari aplikasi. \\
\hline
\end{tabular}

Pada Tabel 5, dijelaskan bahwa terdapat 7 scene yang akan dibuat yaitu intro, menu utama, menu materi, sub menu materi, menu kuis, tentang, dan scene keluar. Dalam mendesain rancangan aplikasi pembelajaran, diperlukan sebuah rancangan struktur navigasi untuk memberi gambaran jelas tentang alur yang digunakan untuk penyusunan aplikasi dijelaskan pada Gambar 2.

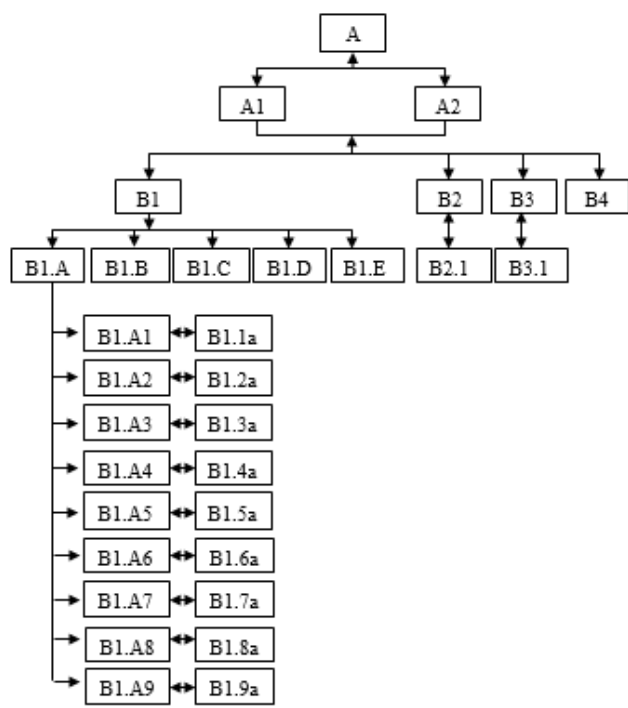

Gambar 2. Struktur navigasi rancangan isi sistem.

Keterangan :

$\begin{array}{llll}\text { A } & \text { : Halaman Utama } & \text { B1.4a } & \text { : Isi Sub Menu Mat } 4 \\ \text { A1 } & \text { : Menu Utama 1 } & \text { B1.5a } & \text { : Isi Sub Menu Mat 5 } \\ \text { A2 } & \text { : Menu Utama 2 } & \text { B1.6a } & \text { : Isi Sub Menu Mat 6 } \\ \text { B1 } & \text { : Menu Materi (Mat) } & \text { B1.7a } & \text { : Isi Sub Menu Mat 7 } \\ \text { B1.A1 } & \text { : Sub Menu Mat 1 } & \text { B1.8a } & \text { : Isi Sub Menu Mat } 8 \\ \text { B1.A2 } & \text { : Sub Menu Mat 2 } & \text { B1.9a } & \text { : Isi Sub Menu Mat 9 } \\ \text { B1.A3 } & \text { : Sub Menu Mat 3 } & \text { B2 } & \text { : Menu Kuis } \\ \text { B1.A4 } & \text { : Sub Menu Mat 4 } & \text { B2.1 } & \text { : Isi Menu Kuis } \\ \text { B1.A5 } & \text { : Sub Menu Mat 5 } & \text { B3 } & \text { : Menu Tentang } \\ \text { B1.A6 } & \text { : Sub Menu Mat 6 } & \text { B3.1 } & \text { : Isi Menu Tentang } \\ \text { B1.A7 } & \text { : Sub Menu Mat 7 } & \text { B4 } & \text { : Tombol Keluar } \\ \text { B1.A8 } & \text { : Sub Menu Mat 8 } & \text { B1.A } & \text { : Sub Menu Materi Planet } \\ \text { B1.A9 } & \text { : Sub Menu Mat } 9 & \text { B1.B } & \text { : Sub Menu Materi Gerhana } \\ \text { B1.1a } & \text { : Isi Sub Menu Mat 1 } & \text { B1.C } & \text { : Sub Menu Materi Rotasi \& Revolusi } \\ \text { B1.2a } & \text { : Isi Sub Menu Mat 2 } & \text { B1.D } & \text { : Sub Menu Materi Benda Langit }\end{array}$




\section{Material Collecting (Pengumpulan bahan)}

Pada tahap ini dilakukan pengumpulan bahan sesuai dengan kebutuhan yang dikerjakan. Bahanbahan tersebut antara lain gambar, audio, background, animasi, dan pendukung lainnya. Bahan yang diperoleh pada tahap ini akan digunakan pada tahap produksi, di mana semua scene untuk aplikasi multimedia ditetapkan.

\section{Assembly (Pembuatan)}

Tahap assembly merupakan tahap di mana seluruh objek multimedia dibuat berdasarkan storyboard dan struktur navigasi yang berasal dari tahap design. Dalam tahap ini, dilakukan pembuatan ilustrasi menggunakan software CorelDraw X7, editing audio menggunakan software Adobe Audition CS6, dan untuk membangun program menggunakan software Adobe Flash CS6. Berikut merupakan hasil screenshot aplikasi media pembelajaran yang telah dibuat.

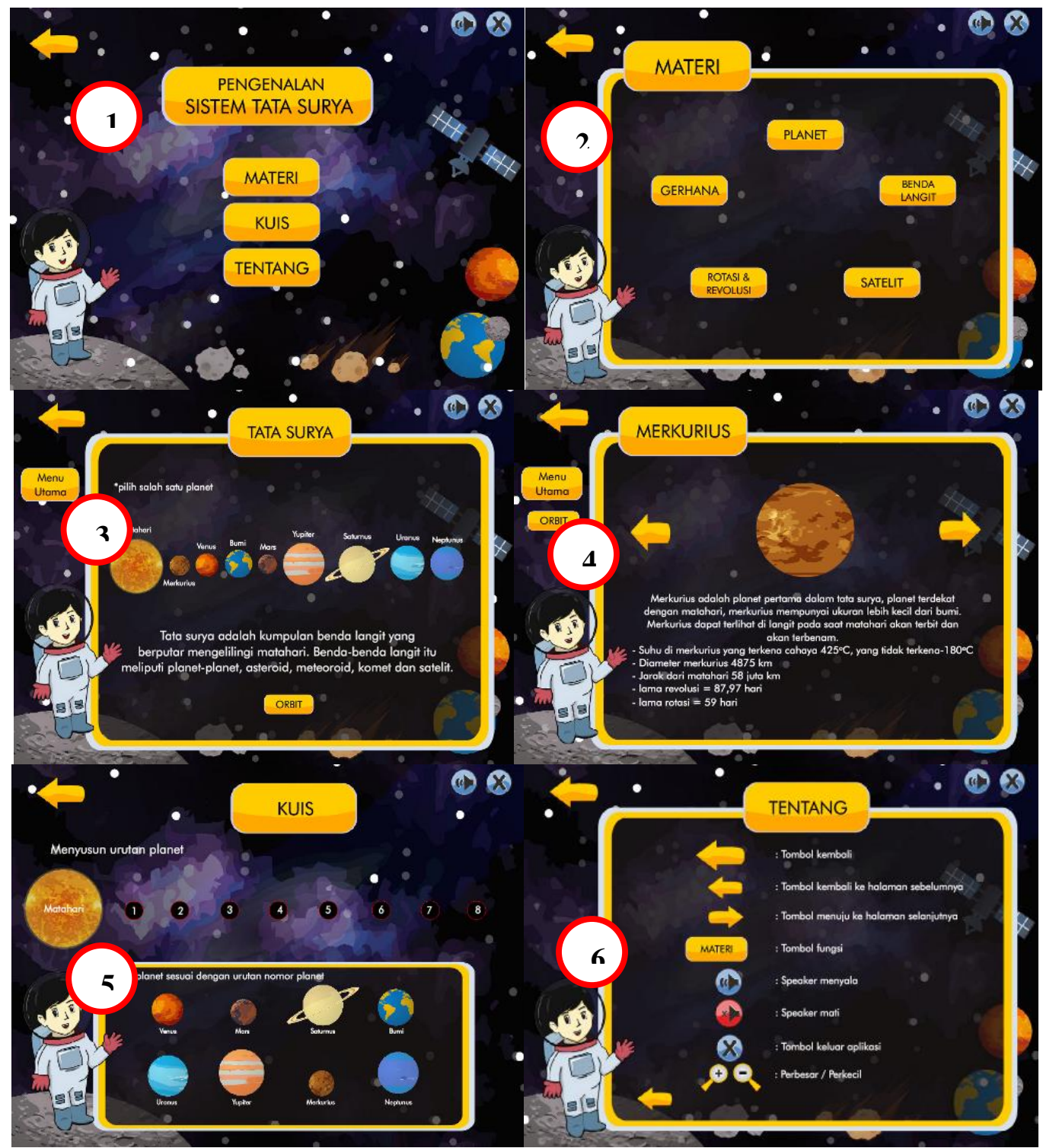

Gambar 3. Tampilan Intro (1), Menu Materi (2), Menu Materi Planet (3), Sub Menu Materi (4), Menu Kuis (5), dan Tentang (6)

Pada menu utama ini terdapat menu materi, menu kuis, menu tentang, tombol keluar, dan tombol sound. Menampilkan 5 Sub Menu Materi yaitu, Planet, Gerhana, Rotasi \& Revolusi, Benda Langit, dan 
Satelit. Menu Materi Planet menampilkan sub menu materi yaitu materi 1, 2, 3, 4, 5, 6, 7, 8, 9. Tiap-tiap sub menu mempunyai fungsi masing-masing serta terdapat tombol kembali ke materi. Sub Menu Materi merupakan isi dari Menu Materi berisi penjelasan dari sub menu yang dipilih. Menu kuis berisi permainan sesuai dengan materi yang diberikan. Menu tentang, berisi informasi aplikasi dan identitas pembuat aplikasi.

\section{Testing (Pengujian)}

Tahap pengujian yang dilakukan pada pengembangan yaitu unit testing dan black box testing. Unit testing merupakan pengujian yang dilakukan untuk melihat apakah baris program yang diberikan telah sesuai dengan yang diinginkan yaitu tombol-tombol yang dibuat telah berfungsi. Sedangkan black box testing ditujukan untuk menguji kesesuaian unit program dengan hasil perancangan pada bab sebelumnya. Cara pengujian ini dilakukan dengan mengamati jalannya unit atau modul kemudian membandingkan dengan hasil yang diharapkan.

\section{Distribution (Distribusi)}

Setelah tahapan testing, dilakukan pembuatan master file, pedoman penggunaan aplikasi, serta dokumentasi sistem. Pada tahap ini, aplikasi telah dikembangkan, digandakan, dan diberikan kepada pengguna. Distribusi yang dilakukan pada penelitian ini yaitu mengubah menjadi aplikasi dengan ekstensi .exe agar dapat dijalankan pada komputer yang terdapat di kelas.

\subsection{Uji Validitas Model}

\subsubsection{Uji Validasi Ahli Materi dan Responden}

Selanjutnya, dilakukan uji validitas yang melibatkan pengguna. Dari hasil uji coba dilakukan, perbaikan sesuai dengan saran masukan dari pengguna. Dari hasil perbaikan, dilakukan uji coba lagi agar meningkatkan kinerja aplikasi sehingga memenuhi kebutuhan untuk evaluasi hasil sistem tersebut. Jika terjadi kesalahan, maka proses akan masuk kembali ke tahap konsep. Apabila tidak terjadi kesalahan, maka proses akan masuk ke tahap selanjutnya.

Tabel 6. Hasil analisis menggunakan media pembelajaran.

\begin{tabular}{ccc}
\hline Tingkat Penilaian & Jumlah & Persentase \\
\hline Sangat Kurang & - & - \\
\hline Kurang & - & - \\
\hline Baik & 4 & $19,05 \%$ \\
\hline Sangat Baik & 17 & $80,95 \%$ \\
\hline Jumlah & 21 & $100 \%$ \\
\hline
\end{tabular}

Berdasarkan Tabel 6, hasil analisis perhitungan skala Likert kuesioner penggunaan media pembelajaran mempunyai respons yang bagus. Penilaian "Sangat Kurang" berjumlah 0 (0\%), "Kurang" berjumlah 0 (0\%), "Baik" berjumlah 4 (19,05\%) dan "Sangat Baik" berjumlah 17 (80,95\%). Hal ini berarti media pembelajaran yang dibuat mendapatkan respons positif dan telah sesuai untuk digunakan dalam membantu pembelajaran.

\subsubsection{Eksperimen Pretest-Treatment-Posttest}

Penelitian [12] mengembangkan animasi interaktif pembelajaran galaksi tata surya. Hasil penelitian tersebut menggunakan kuesioner yang diberikan kepada siswa SMK sebanyak 30 orang kemudian dihitung menggunakan persentase. Hasil dari penelitian menyatakan bahwa sebanyak $(64 \%)$ setuju dan 33\% sangat setuju animasi interaktif ini dapat digunakan sebagai penunjang belajar. Produk animasi interaktif pembelajaran galaksi tata surya ini sangat membantu menarik minat siswa untuk belajar. Penelitian [13] melakukan analisis kepuasan pengguna aplikasi media interaktif pembelajaran tata surya pada siswa sekolah dasar dengan menggunakan framework PIECES. Hasil penelitian menunjukkan bahwa nilai tingkat kepuasan perhitungan skala Likert pada masing-masing PIECES yaitu Performance, Information and Data, Economics, Control and Security, Efficiency, dan Service memiliki nilai lebih dari 3,5. Hal ini menandakan adanya kepuasan dari pengguna dalam menggunakan media interaktif. Pada penelitian [12] dan [13], analisis data yang digunakan yaitu masih menggunakan perhitungan manual tanpa melihat seberapa besar pengaruh dan nilai signifikan dari penggunaan media interaktif. Penelitian ini melakukan analisis data dengan menggunakan uji paired $\mathrm{T}$ dengan software SPSS, sehingga dapat dilihat seberapa besar peningkatan penggunaan media interaktif. 
Tabel 7. Hasil tes pretest postest media pembelajaran

\begin{tabular}{lcc}
\hline \multirow{2}{*}{ No } & \multicolumn{2}{c}{ Nilai Tes } \\
\cline { 2 - 3 } & $\begin{array}{c}\text { Pretest } \\
\text { (sebelum) }\end{array}$ & $\begin{array}{c}\text { Postest } \\
\text { (sesudah) }\end{array}$ \\
\hline 1. & 56 & 70 \\
\hline $\mathbf{2 .}$ & 72 & 92 \\
\hline $\mathbf{3 .}$ & 67 & 87 \\
\hline $\mathbf{4 .}$ & 58 & 82 \\
\hline $\mathbf{5 .}$ & 70 & 89 \\
\hline $\mathbf{6 .}$ & 68 & 85 \\
\hline $\mathbf{7 .}$ & 75 & 90 \\
\hline
\end{tabular}

\begin{tabular}{lcc}
\hline & \multicolumn{2}{c}{ Nilai Tes } \\
\cline { 2 - 3 } No & $\begin{array}{c}\text { Pretest } \\
\text { (sebelum) }\end{array}$ & $\begin{array}{c}\text { Postest } \\
\text { (sesudah) }\end{array}$ \\
\hline 8. & 70 & 85 \\
\hline $\mathbf{9 .}$ & 68 & 80 \\
\hline $\mathbf{1 0}$ & 58 & 85 \\
\hline $\mathbf{1 1 .}$ & 65 & 85 \\
\hline $\mathbf{1 2 .}$ & 70 & 82 \\
\hline $\mathbf{1 3}$. & 75 & 80 \\
\hline $\mathbf{1 4}$ & 68 & 89 \\
\hline
\end{tabular}

\begin{tabular}{ccc}
\hline \multirow{2}{*}{ No } & \multicolumn{2}{c}{ Nilai Tes } \\
\cline { 2 - 3 } & $\begin{array}{c}\text { Pretest } \\
\text { (sebelum) }\end{array}$ & $\begin{array}{c}\text { Postest } \\
\text { (sesudah) }\end{array}$ \\
\hline $\mathbf{1 5 .}$ & 72 & 82 \\
\hline $\mathbf{1 6 .}$ & 75 & 80 \\
\hline $\mathbf{1 7}$. & 75 & 82 \\
\hline $\mathbf{1 8}$. & 68 & 82 \\
\hline $\mathbf{1 9}$ & 62 & 75 \\
\hline $\mathbf{2 0}$. & 70 & 85 \\
\hline $\mathbf{2 1}$. & 75 & 90 \\
\hline
\end{tabular}

Berdasarkan Tabel 7, hasil tes yang dilakukan mengalami perubahan nilai sebelum memakai media pembelajaran dan sesudah memakai media pembelajaran. Hal ini dilakukan untuk menghitung apakah perubahan nilai tersebut signifikan, antara hasil belajar menggunakan media pembelajaran. Berikut adalah tabel perhitungan menggunakan uji paired $t$-test dengan SPSS:

Tabel 8. Hasil analisis paired samples statistics.

\begin{tabular}{llllcc}
\hline & & Mean & N & Std. Deviation & Std. Error Mean \\
\hline \multirow{2}{*}{ Pair 1} & awal & 68.43 & 21 & 5.827 & 1.272 \\
\cline { 2 - 6 } & akhir & 83.67 & 21 & 5.209 & 1.137 \\
\hline
\end{tabular}

Tabel 8 menunjukkan bahwa terdapat perubahan mean sebelum dan sesudah menggunakan media pembelajaran Pengenalan Sistem Tata Surya. Rata-rata atau mean pada pretest adalah 68.43 dan rata-rata posttest sebesar 83.67. Hal ini menunjukkan bahwa adanya peningkatan yang cukup signifikan antara sebelum dan sesudah penggunaan media pembelajaran interaktif.

Tabel 9. Hasil analisis paired samples correlations.

\begin{tabular}{lllcl}
\hline & & $\mathrm{N}$ & Correlation & Sig. \\
\hline Pair 1 & awal \& akhir & 21 & .456 & .038 \\
\hline
\end{tabular}

Tabel 9 merupakan tabel paired sample correlations yang digunakan untuk menganalisis apakah terdapat hubungan antara korelasi nilai sebelum dan nilai sesudah. Dengan jumlah data sebanyak 21 (siswa), terlihat nilai korelasi antara respons pertama (pretest) dengan respons kedua (postets) adalah lemah $(0.456)$.

Tabel 10. Hasil analisis paired samples test.

\begin{tabular}{|c|c|c|c|c|c|c|c|c|c|}
\hline & & \multicolumn{5}{|c|}{ Paired Differences } & \multirow{3}{*}{$\mathbf{t}$} & \multirow{3}{*}{ df } & \multirow{3}{*}{$\begin{array}{c}\text { Sig. } \\
(2- \\
\text { tailed) }\end{array}$} \\
\hline & & \multirow[t]{2}{*}{ Mean } & \multirow{2}{*}{$\begin{array}{c}\text { Std. } \\
\text { Deviation }\end{array}$} & \multirow{2}{*}{$\begin{array}{l}\text { Std. Error } \\
\text { Mean }\end{array}$} & \multicolumn{2}{|c|}{$\begin{array}{c}95 \% \text { Confidence Interval } \\
\text { of the Difference }\end{array}$} & & & \\
\hline & & & & & Lower & Upper & & & \\
\hline Pair 1 & $\begin{array}{l}\text { awal - } \\
\text { akhir }\end{array}$ & -15.238 & 5.778 & 1.261 & -17.868 & -12.608 & -12.085 & 20 & .000 \\
\hline
\end{tabular}

Nilai probabilitas atau Sig. $(0.000)<\alpha$, maka dapat disimpulkan bahwa terdapat perbedaan yang signifikan antara hasil belajar pada data pretest dan posttest. Hal ini menandakan bahwa ada pengaruh penggunaan media pembelajaran dalam meningkatkan keaktifan dan penguasaan konsep siswa, dilihat dari adanya peningkatan hasil belajar mata pelajaran pengenalan sistem tata surya pada siswa kelas VI Sekolah Dasar.

\section{Kesimpulan}

Berdasarkan hasil dari perhitungan quasy experiment dengan rancangan penelitian one group pretest postest, media interaktif yang dibuat berpengaruh positif bagi keaktifan dan penguasaan konsep siswa, terbukti dari adanya rata-rata mean pada pretest dan posttest sebesar 15.238 atau sebesar 22,27\%. Pemberian respons secara realtime juga didapat dari fitur kuis yang ada dalam media pembelajaran, sehingga siswa dapat langsung mengetahui jawaban atas soal-soal yang dikerjakan. Beberapa saran yang dapat dilakukan untuk peneliti selanjutnya seperti penambahan fitur untuk menambahkan soal sehingga soal pada kuis yang digunakan dapat bersifat dinamis atau membuat fitur kuis menjadi sebuah game yang dapat dimainkan oleh banyak siswa. 


\section{Daftar Pustaka}

[1] F. N. Kurdi, "Penerapan Student-Centered Learning dari Teacher-Centered Learning Mata Ajar Ilmu," pp. 108-113.

[2] I. A. Astuti, M. Suyanto, J. R. Road, and C. Catur, "Penerapan Metode User Centered Design pada Game Based," vol. 2, no. 1, pp. 10-20, 2017.

[3] O. Pada and B. Aljabar, "Pengembangan media pembelajaran al-smart untuk materi operasi pada bentuk aljabar," pp. 421-427, 2018.

[4] A. Sudrajat, "Media Pembelajaran," Media Pembelajaran, pp. 1-3, 1977.

[5] R. Rizki et al., "Pengembangan Video Pembelajaran Matematika Berbantuan Media Sosial Instagram sebagai Alternatif Pembelajaran 1," vol. 1, no. 2, pp. 209-215, 2018.

[6] I. E. Putra, "Teknologi Media Pembelajaran Sejarah Melalui," vol. 1, no. 2, pp. 20-25, 2013.

[7] A. Ratnasari, P. Studi, P. Akuntansi, F. Keguruan, D. A. N. Ilmu, and U. M. Surakarta, "Melalui Media Pembelajaran Berbasis Modul Interaktif Adobe Flash CS6 Pada Materi Jurnal Penyesuaian Kelas X Akuntansi Di SMK Negeri 1 Boyolali,” 2018.

[8] S. Husein, L. Herayanti, and Gunawan, "Pengaruh Penggunaan Multimedia Interaktif Terhadap Penguasaan Konsep dan Keterampilan Berpikir Kritis Siswa Pada Materi Suhu dan Kalor," vol. II, no. 2, pp. 136-142, 2016.

[9] E. Sutarno et al., "Pengembangan Model Pembelajaran Berbasis Multimedia Kemandirian Belajar Siswa SMP di Kota Bandung," no. 3, pp. 203-218.

[10] E. Prasetya, A. Sugara, and M. Pratiwi, "Pengembangan Media Pembelajaran Interaktif dengan Menggunakan Metode Multimedia Development Life Cycle,” vol. 2, no. 2, pp. 121-126, 2017.

[11] S. Nurajizah, "Implementasi Multimedia Development Life Cycle Pada Aplikasi Pengenalan Lagu Anak-Anak Berbasis Multimedia," J. Prosisko, vol. 2, no. 2, p. 6, 2016.

[12] S. Anardani and I. D. Kurniawati, "Pengembangan animasi interaktif pembelajaran galaksi tata surya dengan pemodelan luther," vol. 3, 2018.

[13] S. Dasar, "Analisa kepuasan pengguna aplikasi media interaktif pembelajaran tata surya pada siswa sekolah dasar," pp. 21-33, 2017. 